\section{Flying into history}

Richard Mabey

Biographies for Birdwatchers: The Lives of Those Commemorated in Western Palearctic Bird Names. By Barbara and Richard Mearns. Academic: 1988. Pp. 490. £17.50, \$35.

SHould birds, like dahlias and diseases, be named after people? It is a practice that has survived into the twentieth century, yet it seems a curious hangover from the age of magic, this occasional appropriation of a living creature for the person who first identified it, or shot it, or who just happened to be inspiring the namer at the time.

In this exhaustive study, Barbara and Richard Mearns have sketched the biographies of all 91 people who figure in the scientific or popular names of Western Palearctic birds. They are a motley bunch, chiefly from the nineteenth century. The clergy are strongly represented, as are army officers and colonial servants, for whom exploration was part of the job. Britain heads the list, with 29 subjects, followed by Germany with 25 . Only three women feature, and one of these is the unfortunate Thekla Brehm, who died - quite uninterested in birds when she was 24 , and was commemorated in Thekla's lark by her grieving naturalist father.

It is a long book, intended to be used for reference. But enquirers within should be warned that they may not find kindred spirits behind their favourite species. The Northumberland engraver Thomas Bewick, who learned his craft by copying the inscriptions from gravestones, certainly deserved to have a swan named after him (by William Yarrell). But it is not so pleasant to read of the antics of the man commemorated in one of the Mediterranean's commonest warblers. Franco Bonelli (1784-1830) was a zoologist from Piedmont whose notebooks describe 146 methods of catching birds. He 'so admired' his eponymous warbler that he kept one in a cage to study its plumage changes. Colonel George Montagu, of Montagu's harrier, was no better, a great collector and slaughterer who nonetheless had the temerity to lament the havoc caused by this kind of behaviour in others.

Eleonora of Arborea (c. 1350-1404) sounds altogether more interesting and worthy. She was a reforming warrior princess, who had Eleonora's falcon named after her in honour of the legislation she passed protecting birds of prey. But the authors suggest that this was simply to guarantee a market in falcons for the nobility, and for a truly honourable and appropriate naming one has to go to the knot, the little wading bird that Camden
It is a fact of history that most nineteenthcentury ornithologists were cold-blooded anatomists, with no great skill in field observation or love for birds, and it is no fault of the Mearns that it is mostly this unedifying aspect of our 'dominion over nature' that is immortalized in the names of birds. They have done a thorough and valuable job of research, even if the results do make them appear a little like Henry Tristram's (of Grackle fame) Griffon vultures, which "took a peculiar interest in taxidermy, scrutinising, head on one side, the whole operation of birdskinning, and perfectly aware of the moment when a morsel would be ready, exhibiting a more than ordinary excitement when they saw the skin drawn back over the head". Personally I would have preferred the more critical response of the Ivory-billed woodpecker captured by Alexander Wilson (Storm petrel and phalarope) which drilled a hole the size of a fist in his wall and covered his room with plaster in its efforts to escape.

There was a parallel nineteenth-century tradition which deplored reckless collecting and favoured the study of live birds in the field, and it is a comment on past social attitudes that none of this school has been commemorated. The last new naming (the Corsican nut-hatch, dubbed Sitta ledanti after the Belgian ecologist Jean-Paul Ledant) was as recent as 1976 , so there may yet be opportunities to mend our ways. I would like to nominate for future coiners the still vacant titles of St Francis and St Cuthbert, Margaret Cavendish and John Clare.

Richard Mabey, 10 Cedar Road, Berkhamsted. Hertfordshire HP4 $2 L A$, UK, is author, among other books, of Gilbert White: Biography of the Author of the Natural History of Selborne (1986).

\section{Observer observed}

\section{Robert M. May}

Gilbert White and His Records: A Scientific Biography. By Paul G. M. Foster. Christopher Helm, London:1988. Pp.240. £19.95.

Gilbert White wrote only one book, The Natural History and Antiquities of Selborne (hereafter Selborne). The book was first published exactly 200 years ago, in 1788 , and since that time new editions have continued to appear at an average rate of slightly more than one per year. The changing styles in the binding, illustration and design of the different editions form a record of changing taste and fashion against which the unchanging popularity of the book itself is remarkable.

Paul Foster is Head of English at the West Sussex Institute of Higher Educa- tion. His book is not a conventional biography, but rather is an enquiry into the intellectual origins of Selborne: into how Gilbert White developed as an observer of the natural world around him, and how his book came into being. Foster, who appears to have an acquaintance with everything written by White (or written to him) that borders on the obsessive, surveys White's writing practices over more than four decades. The material includes: a Garden-Kalender which was kept as a record of the goings-on in the vicarage garden for over 20 years from 1751; the Flora of Selborne which records a concentrated study over the one year 1766; correspondence with a brother who sent White natural history specimens from Gibraltar while he was posted in the garrison there from 1769 to 1772 ; and the meticulous Journals of meteorological and other natural events which White kept from 1768 up to his death in 1793 .

Foster presents this material in a lively 